IRA-International Journal of Management \& Social Sciences

ISSN 2455-2267; Vol.04, Issue 02 (2016)

Pg. no. 494-501

Institute of Research Advances

http://research-advances.org/index.php/RAJMSS

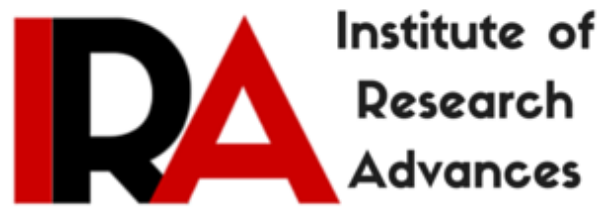

\title{
The Role of Health Tourism on Tourism Development in Kerala State: An Evaluation
}

\author{
${ }^{1}$ Saranya T \\ Senior Research Fellow, \\ Bangalore University, India. \\ ${ }^{2}$ Dr H. K. Mariswamy \\ Professor, Department of Communication, \\ Bangalore University, India.
}

Type of Review: Peer Reviewed.

DOI: http://dx.doi.org/10.21013/jmss.v4.n2.p20

\section{How to cite this paper:}

T, S., \& Mariswamy, H. (2016). The Role of Health Tourism on Tourism Development in Kerala State: An Evaluation. IRA-International Journal of Management \& Social $\begin{array}{llll}\text { Sciences } & \text { (ISSN } & \text { 2455-2267), } & 4(2),\end{array}$ doi:http://dx.doi.org/10.21013/jmss.v4.n2.p20

(C) Institute of Research Advances

\section{(cc) EY-NC}

This work is licensed under a Creative Commons Attribution-Non Commercial 4.0 International License subject to proper citation to the publication source of the work.

Disclaimer: The scholarly papers as reviewed and published by the Institute of Research Advances (IRA) are the views and opinions of their respective authors and are not the views or opinions of the IRA. The IRA disclaims of any harm or loss caused due to the published content to any party. 


\section{ABSTRACT}

Varkala is a tourist hub in Trivandrum in Kerala, India which has high inflow of visitors among other places in Kerala. The place possesses more than 100 resorts in which majority provides Ayurvedic spa and treatment to the customers.

Health and medical tourism is perceived as one of the fastest growing segments in marketing 'Destination India' today. While this area has so far been unexplored, we now find that not only the ministry of tourism, government of India, but also the various state tourism boards and even the private sector consisting of travel agents, tour operators, hotel companies and other accommodation providers are all eying health and medical tourism as a segment with tremendous potential for future growth. The main aim of this project is to find out the scope and relevance of Health Tourism in India particularly with special reference to Varkala. The paper tries to suggest customer friendly measures for the better growth in health tourism. The impact of health tourism on visitors is also analysed here in the study.

\section{Introduction}

According to National Geographic Traveller, Kerala is one among the most favourite and to be seen tourist destinations in the world. The concept of medical tourism is getting momentum in God's Own Country. The concept of Medical Tourism refers to visit by overseas patients for medical treatment and relaxation. The opportunities in Indian Healthcare sector in medical infrastructure and technology are just excel and capable of competing with the one in developed countries.

Patients from various countries are becoming medical tourists to India for low cost and health restorative alternative treatments (Todd, 2005). The medical tourist undergo treatments of a mixture of Ayurveda, yoga, Acupuncture, Oil massage, Nature therapies, and some ancient Indian health care methods-such as Vedic care, and alternate health care service including providing Spa for the body . Kerala, a state in South India, has established itself as a prominent destination of world holiday tourism for its natural beauty and cultural resources. Kerala is a most suitable destination with attractive and serene ambience, friendly and attentive service. The state is also portrayed as "God's own country" (National Geographic, 2004). Kerala has sensed the potential for health holidaying based on its century's old Ayurveda medicinal system. A number of hotels and resorts along with hospitals are offering this treatment in special periods in a year and in special packages.

\section{Components of Health Tourism}

I. Medical tourism: - Persons travel to healthcare destinations for medical treatment like surgery etc; in multi- speciality hospitals.

II. Ayurveda tourism: - Persons are travelling to healthcare destinations for taking ayurvedic treatment in speciality centres.

III. Dental tourism: - Persons travel to healthcare destinations for dental treatment.

IV. Eye Care tourism: - Persons travel to healthcare destinations for seeking treatment in eye care hospitals.

V. Spa tourism: - Persons travel to healthcare destinations for visiting spa resorts.

Siddha/ Unani: - Persons travel to healthcare destinations for taking traditional medicines and Unani.

VI. Yoga and Meditation: - Persons travel to healthcare destinations for practising yoga and meditation.

VII. Kalari Treatment: - Persons travel to healthcare destinations for taking treatment from martial arts masters. 


\section{Review of literature}

- Bindu V.T. Chitramani, P and Babu P. George (2009) explain the observation of medical tourists towards Kerala through serious research. Various issues related to tourist satisfaction such as satisfaction on the idea of post visit, visit and pre-visit are explored. The study identifies the key motivational variables and sources of information used by healthcare tourists. Dimensions of spot preference of Kerala as perceived by alternate medical tourists have also been measured. The paper is concluded with the formulation of a customer retention model for alternate medical tourism in Kerala.

- Vinay Raj $R$ (2013) stresses the importance of health tourism in Kerala where it is growing gradually .The level of satisfaction of tourists and the contradictory of destinations in reality is also mentioned very well in the thesis. The reality observed by the tourists and the contradictions seen when they arrived at the destinations is also addressed. The study finally ended with idea of sustainable development for tourism with satisfactory review and feedbacks after proper research is also described in the study.

- Jyothis T (2009) Emerging trend of healthcare travel can be tapped by creating niche tourism segment known as health tourism. To attract more and more health tourists, a good health tourism destination image should be created by providing standard and satisfying service to the users of health tourism. Health tourists' satisfaction depends upon their expectations and perceptions of services provided by health tourism providers. This study aims to identify the service quality levels of health tourists visited Kerala.

\section{$\underline{\text { Research Methodology }}$}

The study was conducted at Varkala, Trivandrum (a tourist hub for Ayurveda in Kerala) where samples were collected from both foreign and domestic tourists who came for Ayurvedic treatments. The sample technique applied was simple random sampling. In simple random sampling each item in a population has an equal chance of inclusion in the sample. Each individual is chosen randomly and entered by chance, such that each individual has the same probability of being chosen at any stage during the sampling process. The sample size for this study was 200 which divide proportionally with domestic and International tourists among five Ayurvedic resorts in Varkala.

\section{Objectives of the study}

1. To study the role and importance of Ayurveda in promoting health tourism in Kerala with special reference to Varkala.

2. To assess the quality of health tourism practising in Kerala.

3. To understand the relationship between Health tourism and tourism development in Kerala

4. To study the level of satisfaction of the visitors after undergoing health treatments in Kerala.

5. To provide suggestive measures for better advancements in Health Tourism in Kerala.

\section{$\underline{\text { Analysis And Interpretations }}$}

Major Findings of the study

- Demand for Health tourism is increasing swiftly where domestic tourists opt for health treatment more than foreign ones.

\begin{tabular}{|l|l|l|l|l|l|}
\hline Gender & $\begin{array}{l}\text { Total no: } \\
\text { of } \\
\text { variables }\end{array}$ & Agree & Neutral & Disagree & $\%$ \\
\hline Male & 106 & 62 & 11 & 33 & $53 \%$ \\
\hline Female & 94 & 48 & 9 & 37 & $47 \%$ \\
\hline
\end{tabular}


The above table explains that out of total variables of 200,106 (53\%) were male and 94(47\%) were female. In the sub section out of 106 male 62 agreed for the statement, 11 kept neutral and 33 didn't agree for the statement. In the 94 female, 48 agree with the statement, 9 neutral and 37 didn't agree the statement.

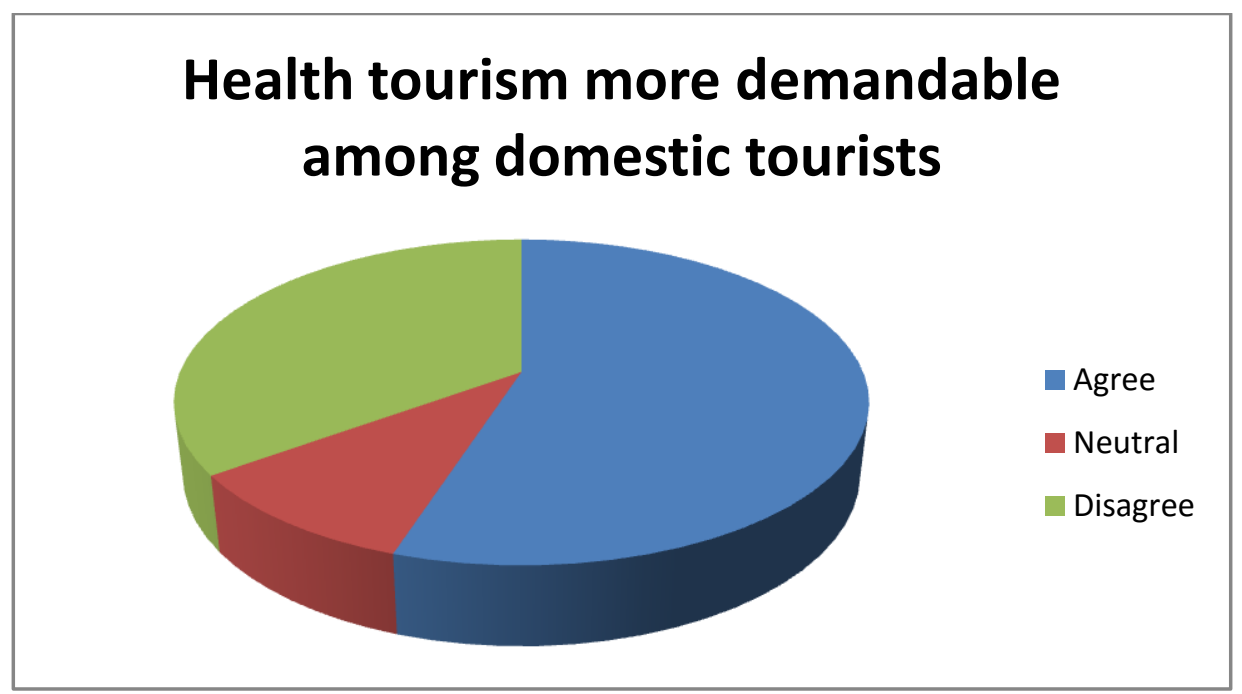

The above pie-diagram reveals a very surprising fact that there is wide increase in the arrival of domestic tourists' not mere touring destinations but for health tourism and related treatments. The domestic tourists including from North-east and other parts of India prefers Ayurvedic treatment here in Kerala. The study this finding was highly noticeable where 110 of respondents easily stood for demand of health tourism among domestic tourists and 20 were Neutral and rest 70 showed their disagree with the statement.

- Ayurveda is preferred by tourists due to its high quality and cheap rate customer friendly packages.

\begin{tabular}{|l|l|l|l|l|l|}
\hline Gender & $\begin{array}{l}\text { Total no: of } \\
\text { variables }\end{array}$ & Agree & Neutral & Disagree & $\%$ \\
\hline Male & 93 & 40 & 14 & 39 & $46.5 \%$ \\
\hline Female & 107 & 48 & 16 & 43 & $53.5 \%$ \\
\hline
\end{tabular}

The above table explains that out of total variables of 200 in which 93(46.5\%) were male and $107(53.5 \%)$ were female. In the sub section out of 93 male 40 agreed for the statement, $14 \mathrm{kept}$ neutral and 39 didn't agree for the statement. In the 107 female, 48 agree with the statement, 16 are neutral and 43 disagree the statement. 


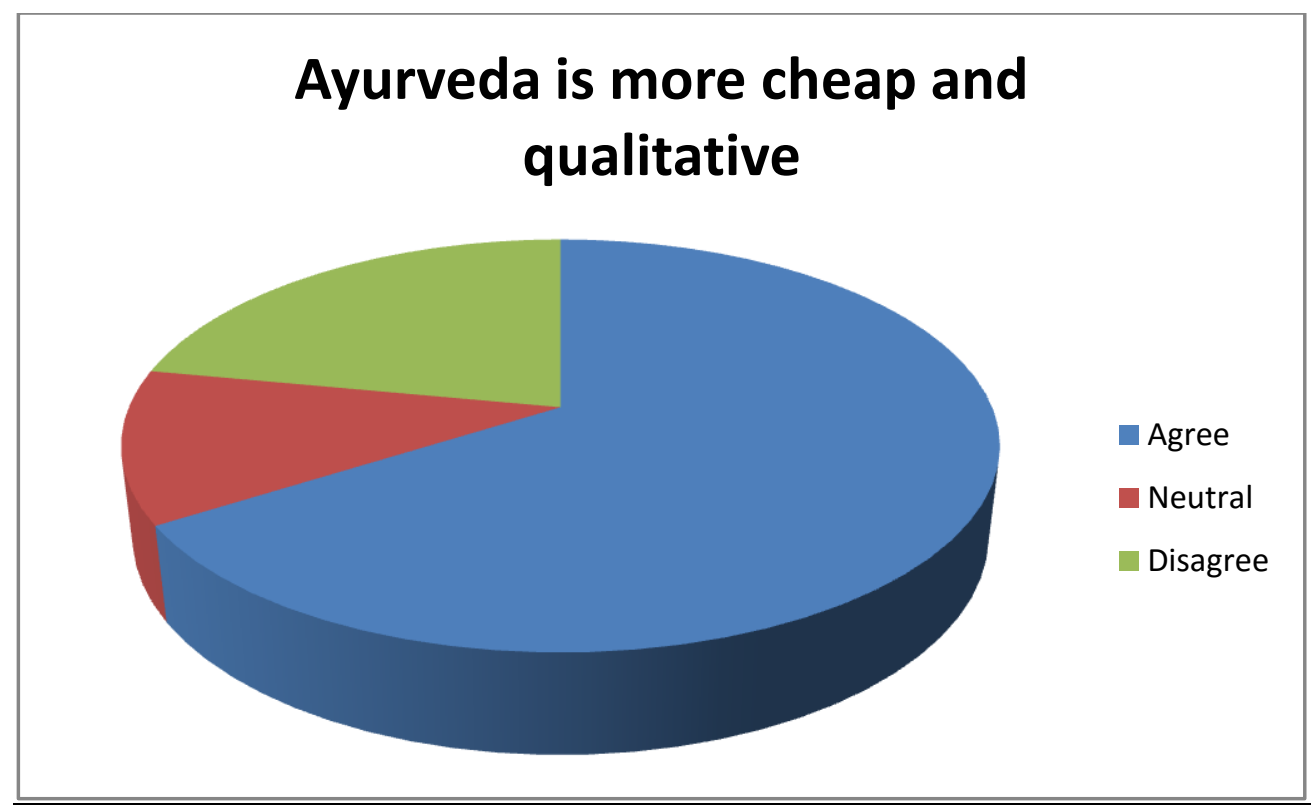

Regarding health treatments, Ayurvedic treatment and spa treatments are considered as the cheapest and highly qualitative one among all other types of treatment. Unani, Homeopathy, Sidha and martial arts occupies a very less position while comparing with Ayurveda. Out of 200 respondents, 88 respondents agreed smoothly about the quality of Ayurveda and 30 didn't give proper comment and 82 disagreed with the statement. Ayurveda is still considered as a unique health treatment practised in Kerala.

- $\quad$ Lack of language interpretations between tourist and the health service provider for better communication is also visible in the study

\begin{tabular}{|l|l|l|l|l|l|}
\hline Gender & $\begin{array}{l}\text { Total no: of } \\
\text { variables }\end{array}$ & Agree & Neutral & Disagree & $\%$ \\
\hline Male & 117 & 96 & 6 & 15 & $58.5 \%$ \\
\hline Female & 83 & 65 & 4 & 14 & $41.5 \%$ \\
\hline
\end{tabular}

The above table explains that out of total variables of 200 in which $117(58.5 \%)$ were male and $108(54 \%)$ were female. In the sub section out of 117 male, 96 agreed for the statement, $6 \mathrm{kept}$ neutral and 15 didn't agree for the statement. In the 83 female, 65 agree with the statement, 4 neutral and 14 disagree the statement. 


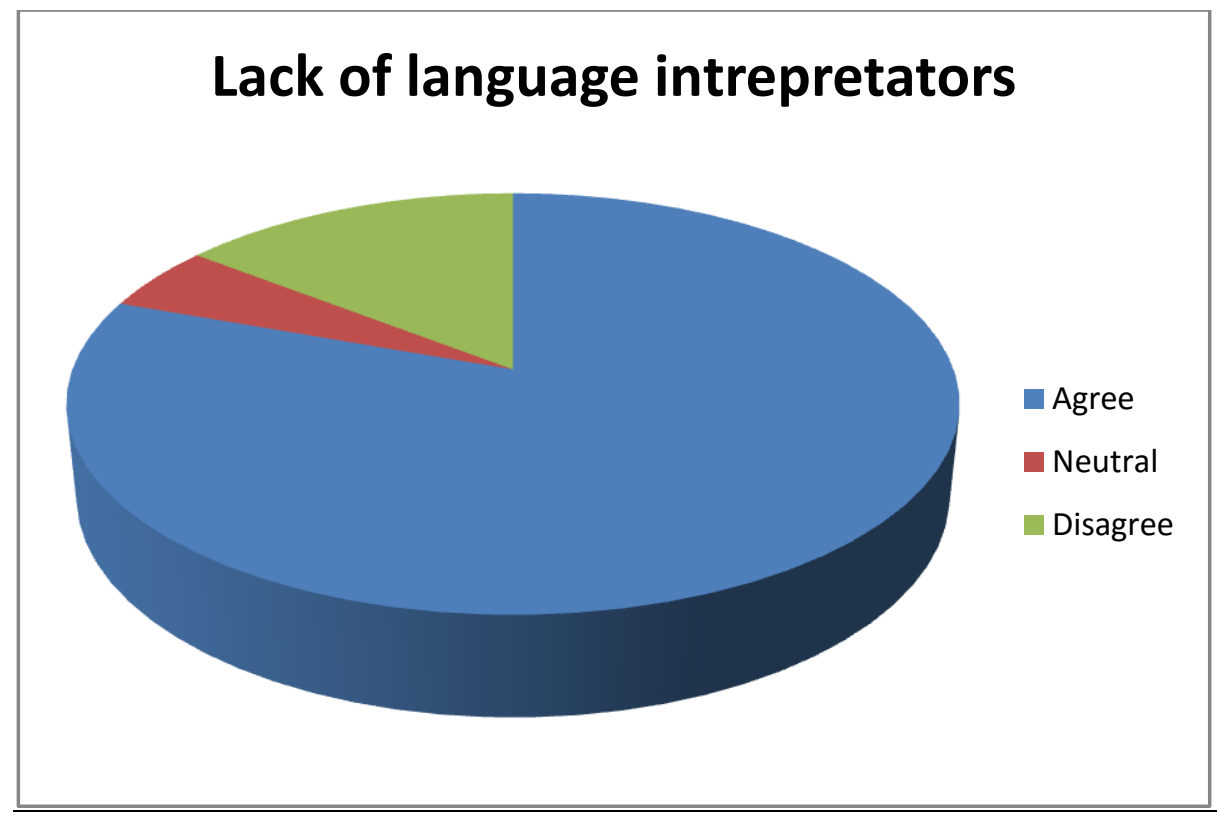

Language barrier was a main hurdle which played a prominent role in this study. The respondents strongly agreed that as tourists they faced the problem of communication while coming to the destination. While undergoing health treatment the foreign tourist says he encounters the problem of proper interaction where the barrier of language plays. People who are in this sector usually spoke regional language and that creates a big problem.161 respondents which forms the major share strongly agreed that there is such a problem where 10 was with no opinion and 29 disagreed with such a statement.

- Advertising strategies for promoting health tourism is not carried out properly.

\begin{tabular}{|l|l|l|l|l|l|}
\hline Gender & $\begin{array}{l}\text { Total no: of } \\
\text { variables }\end{array}$ & Agree & Neutral & Disagree & $\%$ \\
\hline Male & 115 & 63 & 19 & 33 & $57.5 \%$ \\
\hline Female & 85 & 39 & 11 & 35 & $42.5 \%$ \\
\hline
\end{tabular}

The above table explains that out of total variables of 200 in which 115(57.5\%) were male and $85(42.5 \%)$ were female. In the sub section out of 115 male, 63 agreed for the statement, 19 kept neutral and 33 didn't agree for the statement. In the 85 female, 39 agree with the statement, 11 neutral and 35 disagree the statement.

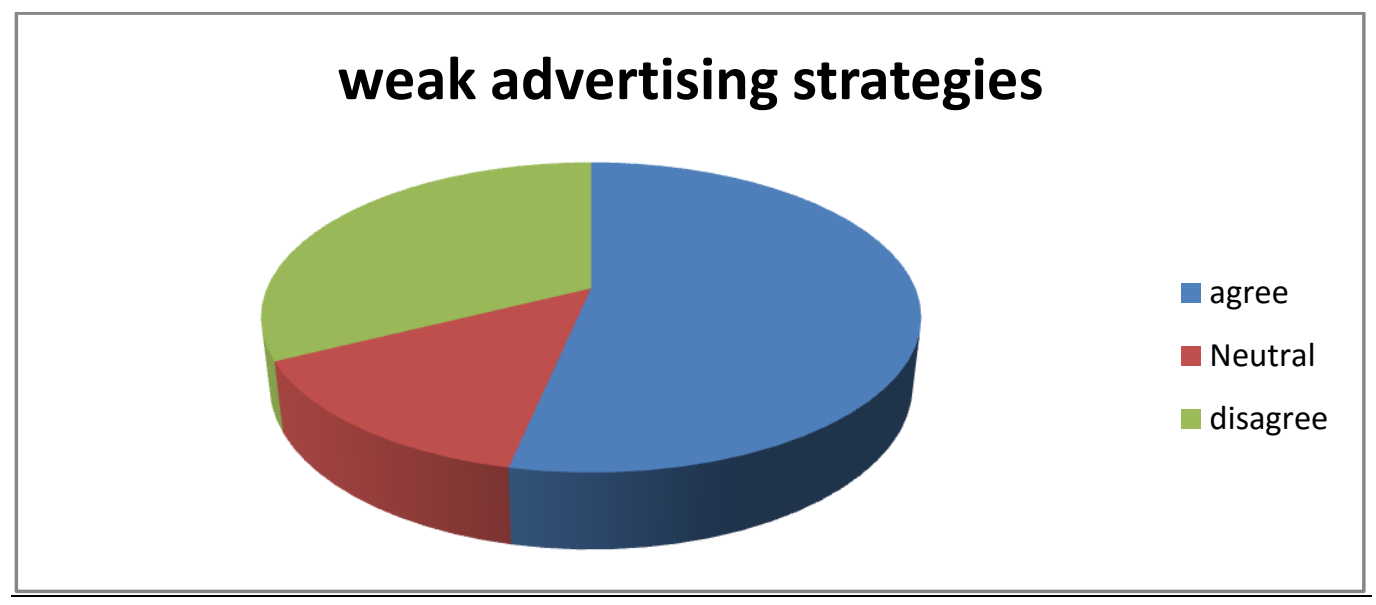


Kerala Tourism Department is running media campaigns for the successful tourism development in Kerala. But the reach of the campaigns among the respondents is highly a debatable issue. Tourists complained about the lack of proper media campaigns for health tourism especially in Varkala, Trivandrum. Proper knowledge about media and the campaigns is a lost hope for them. 102 respondents agreed that advertising campaigns are very weak where 30 had no comments and rest 68 didn't agree the statement.

Rest of the findings are analysed in the form of a graph accommodating all together below.

It was clear that tourists were clearly aware and disappointed by the weak strategies of government over the promotion of health tourism and were mostly describing their disappointment in high dose regarding the new idea of health tourism.

Health treatments are more handled by the local people in the respective destinations in Kerala. The lack of proper language usage was creating a great problem among those who handled the treatment and also for the visitors. Lack of proper language interpretations by experts are also not seen in these areas. The usage of global language was restricted by the local people there. This also created a communication problem among the both.

Health tourism providers failed to provide services in such a way as to meet the expectations of health tourists who want to get quality in treatment, equipment, employees' look planned organisation of cultural and heritage programmes, co-operation, friendliness and translator's services, patient safety and airport pick up services including road safety measures and the quality of roads offered to them to reach their destination.

Regarding women tourists who come for health treatment, they prefer the safety and security angel of their life. Women tourists usually come in groups fearing the security threat. The recent malpractices upon female by the local inhabitants have really tried to bring down the reputation of this field.

The below graph describes the full findings of the study in graphical representation.

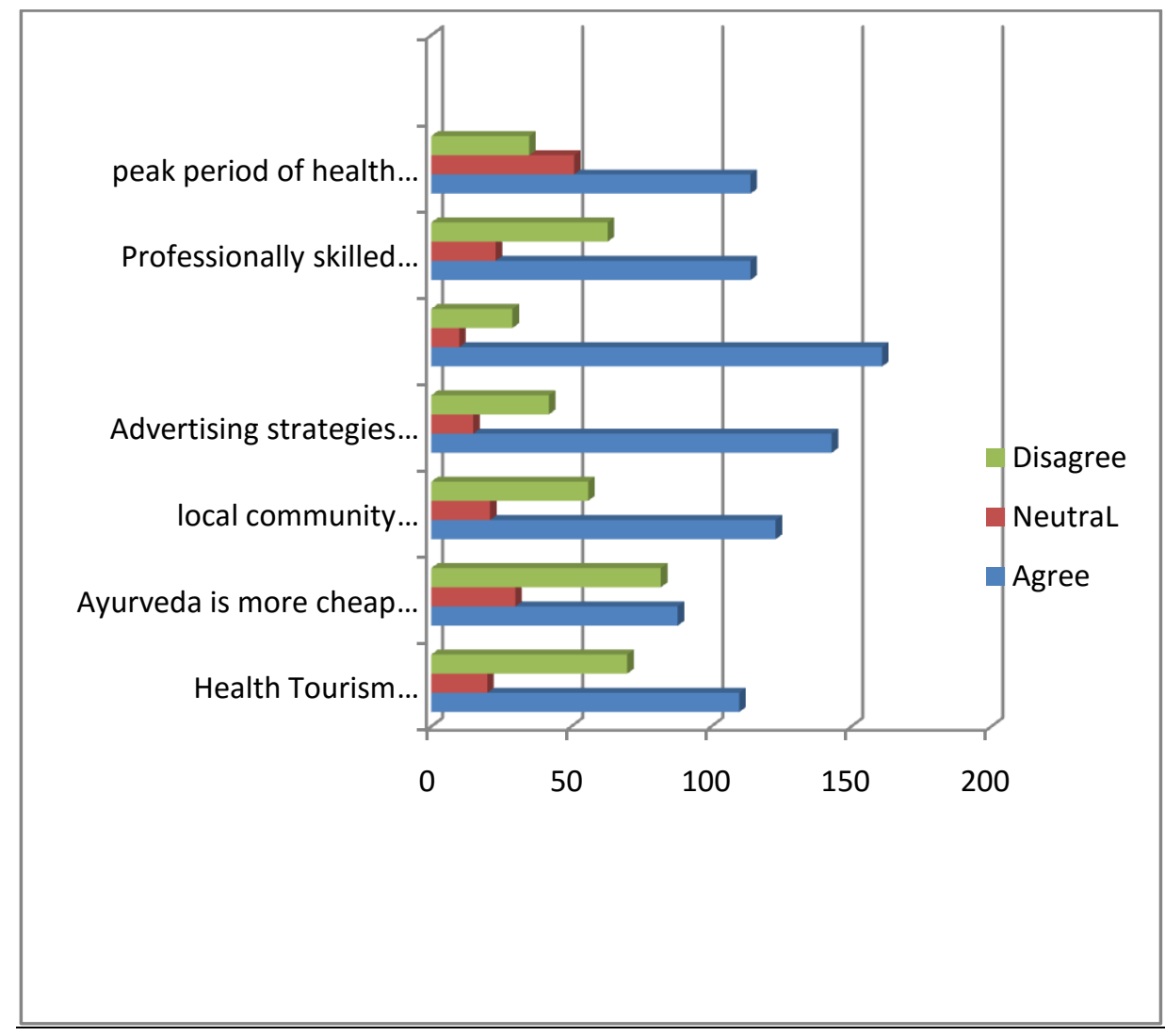


Conclusion

The main aim of the study was to understand the reach of health and medical tourism and its marketing strategies with special reference Varkala, Trivandrum which is a major destination providing health treatment for the visitors. The survey gave me an idea about tourism in Kerala particularly the importance of Health and medical tourism. After the survey I was able to understand the role of tourism in a state's economic policy. There is a clear underlining assurance by Health tourism that it will definitely contribute for the development of Kerala Tourism in the coming years. The uniqueness of Ayurveda needs to be properly studied through great research for the better results in this field.

\section{Bibliography}

- Chawla Romila(2010)Sarjeet Publishers, Tourist Marketing And Communication pp 130-148.

- Connwell and PageV,Zen Book Ltd,Tourism-a modern synthesis.(2013),pp-231-278

- Sinha P C (2011)Kanishka Publishers and Distributors, Tourism issues and strategiespp-156179.

- Das Kumar S(2013)Jaico Publishing House, Research Methodology in Tourism pg 675-786

- Faulkner Bill(2005) Windsley publishers'Aspects of Tourism-Progressing Tourism Research'pp 213-245

G.M.S

(1981)Sarup

\&Sons publishers,TouristMotivation:AnAppraisal.AnnalsofTourismResearch,8(2):187---219.

- Dinnie,K.(2008)Mass Communication Review 22:75-87, Nation Branding: Concepts, issues, practice.

- Krutnik, F. (1991). In a Lonely Street: film noir, genre, and masculinity. London: Routledge.

- Macionis, N. and Sparks, B. (2009). Film-induced tourism: an incidental experience. Tourismreview international 13 (2): 93-102.

- Riley, R., Baker, D. and Van Doren, C.S. (1998). Movie induced tourism. Annals of tourism research, 25 (4): 919-935. 